\title{
Rupture of the right ventricular free wall after myocardial infarction
}

\author{
Ruptura da parede livre do ventrículo direito após infarto do miocárdio
}

\author{
Rômulo César Arnal Bonini ${ }^{1}$, Vladimir Quiroga Verazain ${ }^{2}$, Ricardo M. Mustafa ${ }^{2}$, Yuri Neumman ${ }^{3}$, \\ Margaret Assad ${ }^{4}$, Henrique E. Issa ${ }^{5}$, Ureliano Cintra $^{6}$, Jair J. Golghetto $^{7}$
}

\section{Abstract}

Patient, 75 years-old, with free wall rupture of the right ventricle, corrected with prolene 3.0 points anchored in bovine pericardium patch, promoting the closure of the rupture. The patient was discharged on the $59^{\text {th }}$ day after surgery in good clinical ans laboratorial conditions.

Descriptors: Aneurysm, ruptured. Heart rupture, postinfarction/surgery. Myocardial revascularization. Anterior wall myocardial infarction.
1. PhD in Sciences at Department of Thoracic and Cardiovascular Surgery of the at Faculty of Medicine, University of São Paulo; Head of the Department of Cardiovascular Surgery at Hospital Regional de Presidente Prudente and Professor at Presidente Prudente Medical School, Presidente Prudente, SP, Brazil.

2. Cardiovascular Surgeon at Hospital Regional de Presidente Prudente; Professor at Presidente Prudente Medical School, Presidente Prudente, SP, Brazil.

3. Cardiologist at Department of Cardiovascular surgery at Hospital Regional de Presidente Prudente, Presidente Prudente, SP, Brasil.

4. Cardiologist at Hospital Regional de Presidente Prudente and Coordinator of the Discipline of Cardiology at Presidente Prudente Medical School, Presidente Prudente, SP, Brazil.

5. Interventionist cardiologist at Hospital Regional de Presidente Prudente, Head of the Cardiology Department of the Hospital Regional de Presidente Prudente; Professor at Presidente Prudente Medical School, Presidente Prudente, SP, Brazil.

\section{Resumo}

Paciente de $\mathbf{7 5}$ anos, com ruptura da parede livre do ventrículo direito, corrigida com pontos de prolene 3.0 ancorados em tira de pericárdio bovino, promovendo o fechamento da ruptura. $O$ paciente recebeu alta hospitalar no $59^{\circ}$ dia de pós-operatório, em boas condições clínicas e laboratoriais.

Descritores: Aneurisma Roto. Ruptura cardíaca pós-infarto/ cirurgia. Revascularização miocárdica. Infarto miocárdico de parede anterior.

6. Cardiologist and Echocardiographist at Hospital Regional de Presidente Prudente, Presidente Prudente, SP, Brazil.

7. Head of the Coronary and Postoperative Unit at Hospital Regional de Presidente Prudente, Presidente Prudente, SP, Brazil.

This study was carried out at Department of Cardiovascular Surgery at Hospital Regional de Presidente Prudente, Presidente Prudente, SP, Brazil.

Correspondence address:

Rômulo César Arnal Bonini

Rua Winston Churchill, 234 - apto 1402 - Jardim Paulistano

Presidente Prudente, SP, Brazil - Zip Code 19013-710

E-mail: romulobonini@terra.com.br

Article received on August $26^{\text {th }}, 2011$ Article accepted on December $12^{\text {th }}, 2011$ 


\section{Abbreviations, acronyms and abbreviations}

CPB Cardiopulmonary bypass

LVR Left ventricular free wall rupture

\section{INTRODUCTION}

The cardiac rupture was described by William Harvey in 1647 [1]. In 1850, Joseph Hodgron established the relationship between the cardiac rupture and obstructive coronary heart disease [2]. With high mortality, the natural history of this disease began to change with the first reports of successful surgical correction, performed by Hatcher et al. [3] (1970), and FitzGibbon et al. [4] (1971).

Among the mechanical complications of myocardial infarction, rupture of ventricular free wall is the most serious, with an incidence of $10 \%$ in the left ventricle [5]. Regarding the evolution time, the acute form is characterized by sudden rupture and massive hemorrhage into the pericardial cavity, followed by death in most cases.

In some patients, however, bleeding into the pericardium may be slow and repetitive, with thrombus formation between the epicardium and the pericardial cavity, which contains the bleeding. In such situations, cardiac rupture is called subacute, and the patient can survive for hours or days, which opens the possibility for eventual surgical intervention with success [6-8].

The rupture of the right ventricular free wall after myocardial infarction is a rare entity, reported by Soriano et al. [9], Basarici et al. [10], and De Gennaro et al. [11] as septal rupture associated with right ventricular wall dissection. In other situations other than myocardial infarction, Niclauss et al. [12] described the right ventricular rupture as a result of medistinitis.

\section{CASEREPORT}

75-year-old male patient, caucasian, went to the emergency room of the Hospital Regional of Presidente Prudente - São Paulo - Brazil, complaining of progressive dyspnea for one week, that worsens with exertion, and edema of lower limbs for 2 days. Physical examination revealed the following: in regular condition, pale, hydrated, no fever, tachypnea, dyspnea, and cyanosis of the extremities $(2+/ 4+)$. Blood pressure: $90 \times 70 \mathrm{mmHg}$, heart rate: 90 beats per minute, respiratory rate: 25 breaths per minute.

On cardiac auscultation, heart sounds were hypophonetic, rhythm without murmurs in two stages. On lung auscultation the vesicular murmur was present, with reduced bases with bilateral wheezing. The abdomen was distended and tense, painless on palpation. Lower limbs were swollen $(2+/ 4+)$. The chest $\mathrm{x}$-ray showed an enlarged cardiac silhouette, and blurring of the left costophrenic angle.

The electrocardiogram showed ST segment supraunleveling in leads from $\mathrm{V} 1$ to $\mathrm{V} 4 \mathrm{of} 2 \mathrm{~mm}$. The cardiac enzymes (creatinine phosphokinase - CPK, CPK-MB, and $\mathrm{T} / \mathrm{I}$ troponin) were within the normal pattern. The transthoracic echocardiography showed rupture of the right ventricular free wall of $4 \mathrm{~mm}$ in diameter, without the Doppler flow signals. There was also signs of pericardial effusion with tamponade, major segmental dysfunction (ejection fraction $30 \%$ ) of the left ventricle with anteroapical
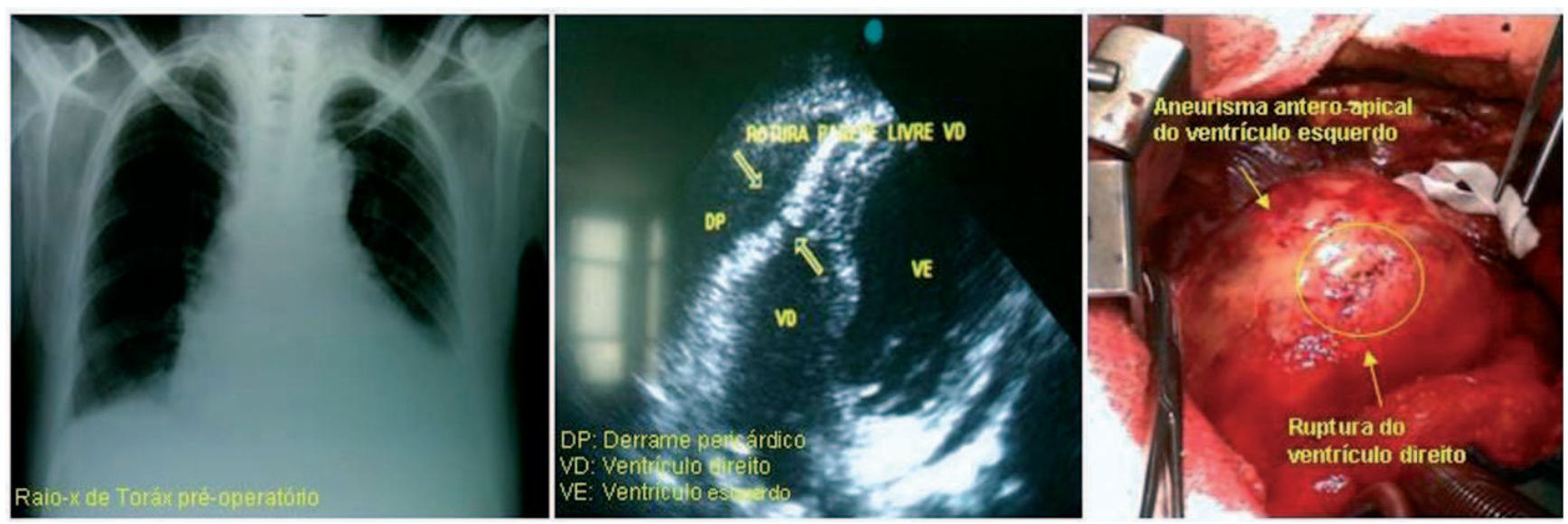

Fig. 1 - Chest radiography, preoperative echocardiography aspect and intraoperative imaging of the rupture 
aneurysm and thrombus. The mitral valve showed mild/ moderate reflux, and left ventricular diastolic diameter was $76 \mathrm{~mm}$. Figure 1 shows the chest X-ray, and echocardiographic and intraoperative spect of the rupture.

The coronary angiography showed proximal occlusion of the anterior interventricular branch of left coronary artery. Surgery was indicated, immediately after diagnosis.

The patient was referred to the operating room, underwent median thoracotomy by sternotomy, and hematic pericardial effusion was found in large quantities, and the presence of clots in the anterior wall of the right ventricle along the anterior interventricular artery, with tamponationof the right ventricle rupture, with no signs active bleeding at the time.

We perfomed systemic heparinization of $4 \mathrm{mg} / \mathrm{kg}$, cannulation of the ascending aorta and right atrium with a single dual-stage cava, installation of cardiopulmonary bypass (CPB) with hypothermia at $33^{\circ} \mathrm{C}$. After stabilization of $\mathrm{CPB}$, we performed aortic clamping, isothermal blood cardioplegia - administered antegradely every 20 minutes. We remove all adherent clots in the heart and visualize the orifice of the right ventricle rupture. The left ventricular aneurysm was approached by longitudinal incision over the anterior interventricular artery. After its opening, we observed a thrombus with recent aspect with diameters of $6 \times 6 \mathrm{~cm}$, which was removed. The septal wall was pale and friable, unlike the left ventricle lateral wall that had aspect of viable tissue. We corrected the rupture of the right ventricle through the septum using prolene 3.0 stitches anchored in bovine pericardium patch, promoting the closure of the right ventricle rupture.

After, we performed the correction of the aneurysm using a technique similar to that proposed by Braile et al. [13] in 1991, and presented by Silveira Filho et al. [14] in 2011. We use a circular patch of bovine pericardium, excluding fibrotic septal wall to reconstruct the left ventricle ("endoventricular circular plasty"), in order to maintain a more physiological cavity. We also peformed revascularization of proximal left anterior interventricular branch using aortocoronary graft from left saphenous vein (Figure 2).

We established patient rewarming at $37^{\circ} \mathrm{C}$, removal of air cavities, unclamping of the aorta after 102 minutes, and after return of heart rate and hemodynamic stability with dobutamine $(5 \mathrm{mg} / \mathrm{kg} / \mathrm{min})$ we disconnected cardiopulmonary bypass after 135 minutes. We reviewed the plans for hemostasis and synthesis. Patient was hemodynamically stable on dobutamine until the $3 \mathrm{rd}$ postoperative day, where he was extubated. Presented with sternal wound dehiscence and mediastinitis on the 10 th postoperative day and underwent resuture wound with antibiotic therapy and maintained for 21 days. The 30-days control echocardiogram revealed a reduction of the left ventricular end-diastolic diameter to $55 \mathrm{~mm}$, improved ejection fraction (49\%), mild mitral valve insufficiency, as well as closure of right ventricular rupture successfully. The patient was discharged on the 59th postoperative day in good clinical and laboratory condition. This study was approved by the Ethics Committee in Research of Universidade do Oeste Paulista, No. 002/RC on 01/10/2010.

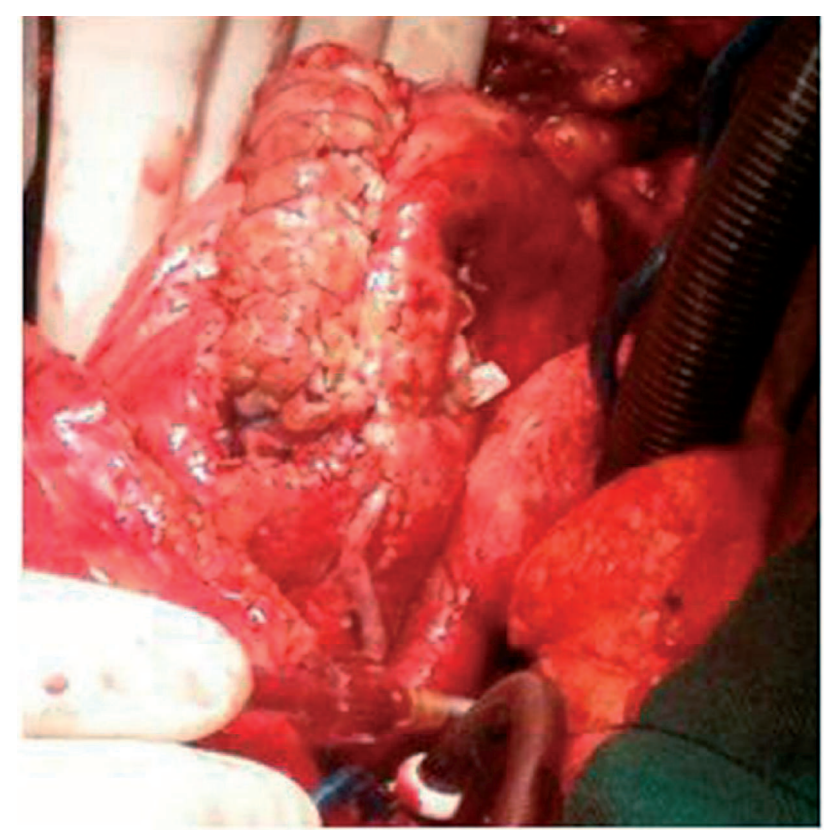

Fig. 2 - Final surgical aspect

\section{DISCUSSION}

Knowledge of disease progression is needed to ensure accurate and timely diagnosis. Due to the rapid deterioration of these patients, there is a mortality rate of $50-80 \%$ in the first week, if not treated. With surgical repair, patients can extend survival to five years to $65 \% 5$. Some authors claim that the myocardial rupture focuses preferentially on singlevessel disease patients. Others suggest the prevalence of triarterial coronary atherosclerosis disease [15]. Abreu Filho et al. [6] found that $33.8 \%$ of patients had single vessel coronary artery disease and Sá et al. [8] found that $66.7 \%$ of patients with ventricular septal rupture after acute myocardial infarction had one-vessel disease.

The anterior myocardial wall is mentioned by several authors as the most likely to suffer ruptura [7], however, authors such as Padró et al. [16] argue that cardiac rupture 
may also occur in any region of the left ventricle, other authors observed higher incidence of rupture in lateral ventricular wall (44\%) [14]. Probably the increased stress on the myocardium lateral wall, resulting from the contraction of the two papillary muscles adjacent to the mitral valve, may facilitate the onset of rupture.

Many patients with myocardium free wall rupture die suddenly, often even without a diagnosis. Abreu Filho et al. [6] observed $98(77.2 \%)$ patients in these conditions, of which only $5(5.1 \%)$ underwent surgery with one $(20 \%)$ survived. The subacute form, in turn, has more slow involvement, allowing its identification and allows for a possible surgical correction. Its exact incidence is not well established, some authors estimate in $30 \%$ the occurrence of subacute cardiac rupture after myocardial infarction.

Abreu Filho et al. [6] observed that, among 127 patients, $29(22.8 \%)$ had subacute rupture, and $19(65.5 \%)$ underwent surgical treatment, with hospital survival of $84.2 \%$. Satisfactory results were also obtained by other authors in the surgical treatment of subacute left ventricular rupture, with $76 \%$ hospital survival [6] .

The treatment of ventricular free wall rupture is essentially surgical. Abreu Filho et al. [6] performed cardipulmonary bypass by this via in five patients with acute cardiac rupture and in six patients with subacute cardiac rupture with unstable clinical presentation. In the first series of cases, surgical correction was performed with the aid of cardiopulmonary bypass and infarctectomy through the affected area.

In the 80's, techniques were proposed seeking the tamponing of the rupted area, by suturing the Teflon patch on the normal subjacente myocardium [16]. With the development of biological glues, alternative procedures to the use of cardiopulmonary bypass and those to avoid the infarctectomy are now used. This method has proved to be the most efficient way to control bleeding and prevent recurrence of rupture [6]. Padró et al. [16] reported treatment of 13 patients with subacute rupture of the left ventricle using this technique, with $100 \%$ long-term survival. In the case of right ventricle rupture specifically, we can observe in the literature, reports of right ventricular wall dissection [9-11] after septal rupture after myocardial infarction. However, this case demonstrates illustratively as the figures shown, it deals with right ventricular free wall rupture with intact ventricular septum.

Thus, we conclude that this patient presented with myocardial infarction over a week of evolution, caused by obstruction of the proximal anterior interventricular branch, without treatment. He evolved clinically with signs of heart failure, presenting a serious complication, a little reported in the literature, that was the subacute rupture of the right ventricular free wall.

\section{REFERENCES}

1. Harvey W. De Circulatio Sanguinis. Exercit 3. Citado por Morgagni GB In: The seats and causes of diseases. Trad. Benjamin Alexander. London: Letter 27;1769. p.830.

2. Reardon MJ, Carr CL, Diamond A, Letsou GV, Safi HJ, Espada R. Ischemic left ventricular free wall rupture: prediction, diagnosis and treatment. Ann Thorac Surg. 1997;64(5):1509-13.

3. Hatcher CR Jr, Mansour K, Logan WD Jr, Symbas PN, Abbott OA. Surgical complications of myocardial infarction. Am Surg. 1970;36(3):163-70.

4. FitzGibbon GM, Hooper GD, Heggtveit HA. Successful surgical treatment of postinfarction external cardiac rupture. Am Surg. 1970;36(3):163-70.

5. Kjeld T, Hassager C, Hjortdal VE. Rupture of free left ventricle wall, septum and papillary muscle in acute myocardial infarction. Ugeskr Laeger. 2009;171(23):1925-9.

6. Abreu Filho CAC, Dallan LAO, Lisboa LAF, Platania F, Iglezias JCR, Cabral RH, et al. Tratamento cirúrgico da rotura de parede livre do ventrículo esquerdo após infarto agudo do miocárdio. Rev Bras Cir Cardiovasc. 2002;17(1):6-12.

7. Dallan LA, Oliveira SA, Abreu Filho C, Cabral RH, Jatene FB, Pêgo-Fernandes PM, et al. Rotura cardíaca após infarto agudo do miocárdio (IAM): uma complicação passível de correção cirúrgica. Rev Bras Cir Cardiovasc. $1993 ; 8(4): 272-81$.

8. Sá MP, Sá MV, Barbosa CH, Silva NP, Escobar RR, Rueda FG, et al. Clinical and surgical profile of patients operated for postinfarction interventricular septal rupture. Rev Bras Cir Cardiovasc. 2010;25(3):341-9

9. Soriano CJ, Pérez-Boscá JL, Canovas S, Ridocci F, Frederico $\mathrm{P}$, Echanove I, et al. Septal rupture with right ventricular wall dissection after myocardial infarction. Cardiovasc Ultrasound. 2005;3:33.

10. Basarici I, Erbasan O, Kemaloglu D, Arslan G, Bayezid O. Exceptional ventricular septal rupture associated with intramyocardial dissection throughout the right ventricle. Echocardiography. 2010;27(4):460-5.

11. De Gennaro L, Brunetti ND, Ramunni G, Buquicchio F, Corriero F, De Tommasi E, et al. Septal rupture with right ventricular wall dissecting haematoma communicating with left ventricle after inferior myocardial infarction. Eur $\mathbf{J}$ Echocardiogr. 2010;11(6):477-81.

12. Niclauss L, Delay D, Stumpe F. Right ventricular rupture due to recurrent mediastinal infection with a closed chest. Interact Cardiovasc Thorac Surg. 2010;10(3):470-2. 
13. Braile DM, Mustafá RM, Santos JLV, Ardito RV, Zaiantchick $\mathrm{M}$, Coelho WMC, et al. Correção da geometria do ventrículo esquerdo com prótese semi-rígida de pericárdio bovino. Rev Bras Cir Cardiovasc. 1991;6(2):109-15.

14. Silveira Filho LM, Petrucci O, Vilarinho KAS, Baker RS, Garcia F, Oliveira PPM, et al. Prótese rígida de pericárdio bovino para remodelamento ventricular esquerdo: 12 anos de seguimento. Rev Bras Cir Cardiovasc 2011;26(2):164-72.
15. Schwarz CD, Punzengruber C, Ng CK, Schauer N, Hartl P, Pachinger O. Clinical presentation of rupture of the leftventricular free wall after myocardial infarction: report of five cases with successful surgical repair. Thorac Cardiovasc Surg. 1996;44(2):71-5.

16. Padró JM, Mesa JM, Silvestre J, Larrea JL, Caralps JM, Cerrón F, et al. Subacute cardiac rupture: repair with a sutureless technique. Ann Thorac Surg. 1993;55(1):20-3. 